\title{
ENVIRONMENTAL ASSESSMENT OF THE HYDRAULIC STRUCTURES BY VARIOUS ARTIFICIALIZATION PARAMETERS
}

\author{
$U D C 626 / 627=111$
}

\author{
Milica Marković ${ }^{1}$, Jelena Marković-Branković \\ ${ }^{1}$ PWMC "Srbijavode", Belgrade, \\ ${ }^{2}$ Faculty of Civil Engineering and Architecture, University of Niš
}

\begin{abstract}
The natural rivers and their flood areas are among the most complex and diverse ecosystems in the world. Traditional structural solutions in river training works are focused on basic requirements as flood protection, littoral zone protection, river bed protection, providing the space for economic development. In this study a method of anticipated assessment of certain physical impact of designed river training works is presented, perceived as global effect of river bed artificialization. The method mainly serves to compare the various possible solutions of river training works, based on the , artificialization parameter" also named ,global impact GI".
\end{abstract}

Key words: river training works, environmental costs

\section{INTRODUCTION}

Rivers and their corridors are complex ecosystems which include the adjacent terrains, the flora and fauna and the water streams.

These ecosystems depend on the water stream conditions, where the flows, the sediments transport, the water temperature and other variables have a significant role [1].

Traditional structural solutions in river training works are focused on basic requirements as flood protection, littoral zone protection, river bed protection, providing the space for economic development.

These solutions may lead to environmental degradation, i.e. alteration of physicalchemical and morphological characteristics of the natural components of the environment, decrease of diversity and biological productivity of natural and anthropogenic ecosystems, impacts on the ecological balance and quality of life.

Received December 1, 2014

Corresponding author: Jelena Marković-Branković

Faculty of Civil Engineering and Architecture, University of Niš, 18000 Niš, Aleksandra Medvedeva 14, Serbia

E-mail: jelena.markovic.brankovic@gaf.ni.ac.rs 
The goal of this study is to present the approach for river training structures environmental assessment [2].

The method mainly serves to compare the various possible solutions of river training works, based on the ,artificialization parameter” also named ,global impact GI”.

The method is interesting while it enables the assessment of the relative influence of various artificialization parameters, thus guiding the selection and the improvement of the proposed solutions.

\section{GLOBAL EFFECT OF RIVER BED ARTIFICIALIZATION}

A method of anticipated assessment of certain physical impact of designed river training works is presented, perceived as global effect of river bed artificialization.

The method mainly serves to compare the various possible solutions of river training works, based on the ,,artificialization parameter” also named ,global impact GI”.

The method is interesting while it enables the assessment of the relative influence of various artificialization parameters, thus guiding the selection and the improvement of the proposed solutions.

Mainly, the method quantifies the "environmental cost" for four elements [3]:

a) the characteristics of the river bed segment possibly affected by the river training works;

b) the river's importance class (river and basin size, environmental and water quality, river flow), called "large river rank";

c) the intensity of the artificialization aggressiveness, generated by the river morphology modification;

d) impact time.

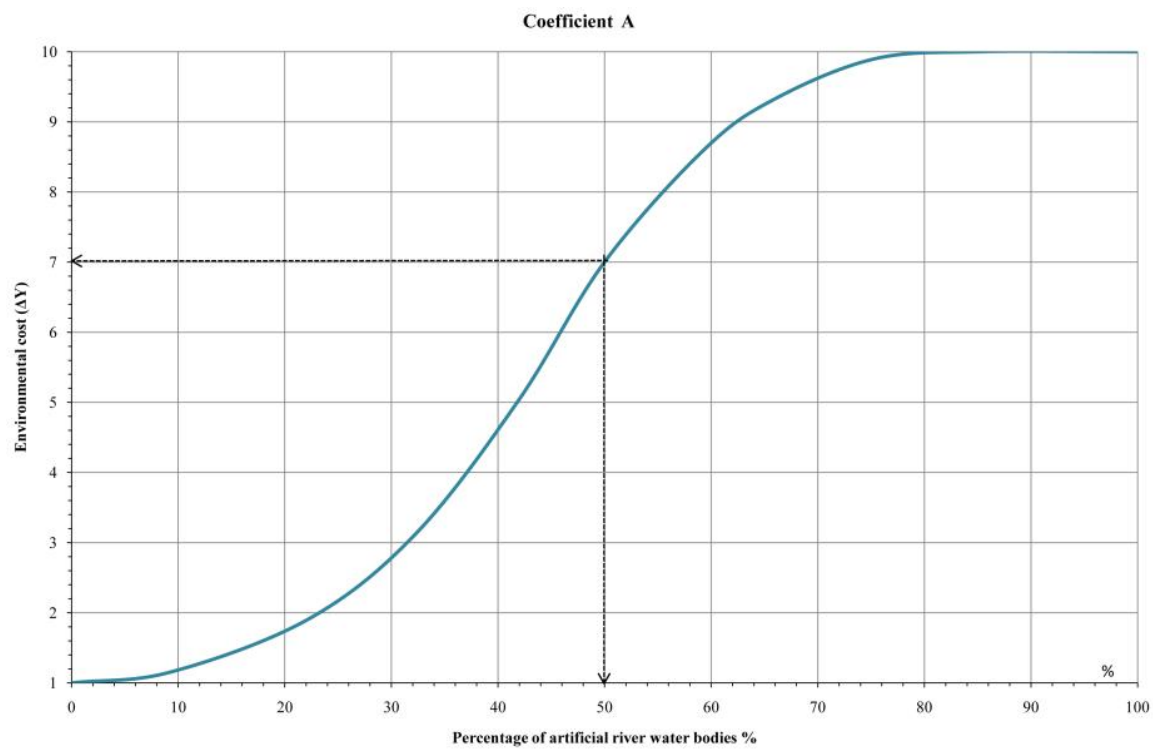

Fig. 1 Environmental cost of river bed artificialization per length unit 
a) The river segment characteristics are quantified by the $\mathrm{A}$ coefficient and the values (environmental cost) are illustrated in figure 1 graph, depending on the artificialized length percentage of the of the analyzed segment length.

Selecting and highlighting of a segment aims to analyze, ecologically and morphologically relatively homogenous river sector, with a recognizable identity and a rather geographic nature. Figure 1 show that the regulation works (and, implicitly, the artificialization) of the two segments have a relatively low global impact: the artificialization of up to $25 \%$ of the segment incurs relatively low environmental cost, since the areas remained under natural conditions are able to maintain a viable ecosystem.

After artificialization of up to $40-50 \%$ of the segment, the environmental costs are spectacularly increasing, indicating the strong risk of morphological or ecological collapse and of the last areas (the last $30 \%$ of the sector) lead to the maximum environmental cost.

b) The large river rank is quantified by the $\mathrm{R}$ coefficient, whose environmental cost value is illustrated in figure 2 graph.

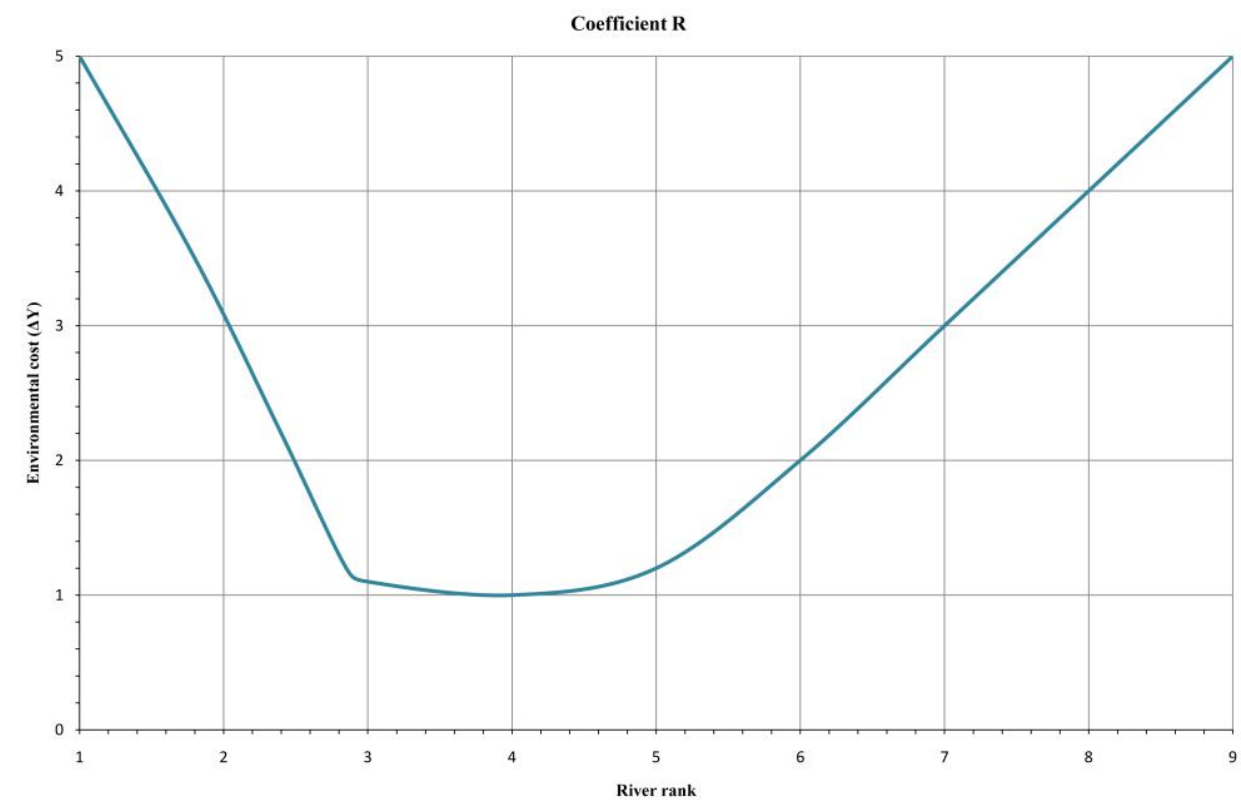

Fig. 2 Environmental cost of river sector artificialization regarding river rank

The high environmental costs impact the rivers of extreme ranks.

Regarding the high rank rivers, of high significance and „value”, the works apparently generate significant, direct and derivative, effects, including high environmental costs.

The lower rank rivers are ecologically destroyed by the river training works.

Thus, the environmental cost is relatively high.

c) The intensity of the impact quantifies the inconsistency between the river conditions subsequent the regulation works and the river morphology which would correspond to its dynamic balance condition. 
For this purpose, eight factors are used.

These factors have a proven importance for the ecological function and 8 distinct parameters providing quantification of the system alteration.

For each $i$ factor $(i=1,2 \ldots 8)$, the environmental cost is entrenched and its value is expressed by the $\mathrm{I}_{i}$ coefficient.

$1^{\text {st }}$ factor - sinuosity loss and decreasing of the multiplying percentage of the parallel river flow routes by comparison with the originating route layout, often encountered on the older maps or aerial pictures. The environmental cost value is expressed by the $\mathrm{I}_{1}$ coefficient and is defined using the graph in figure 3.

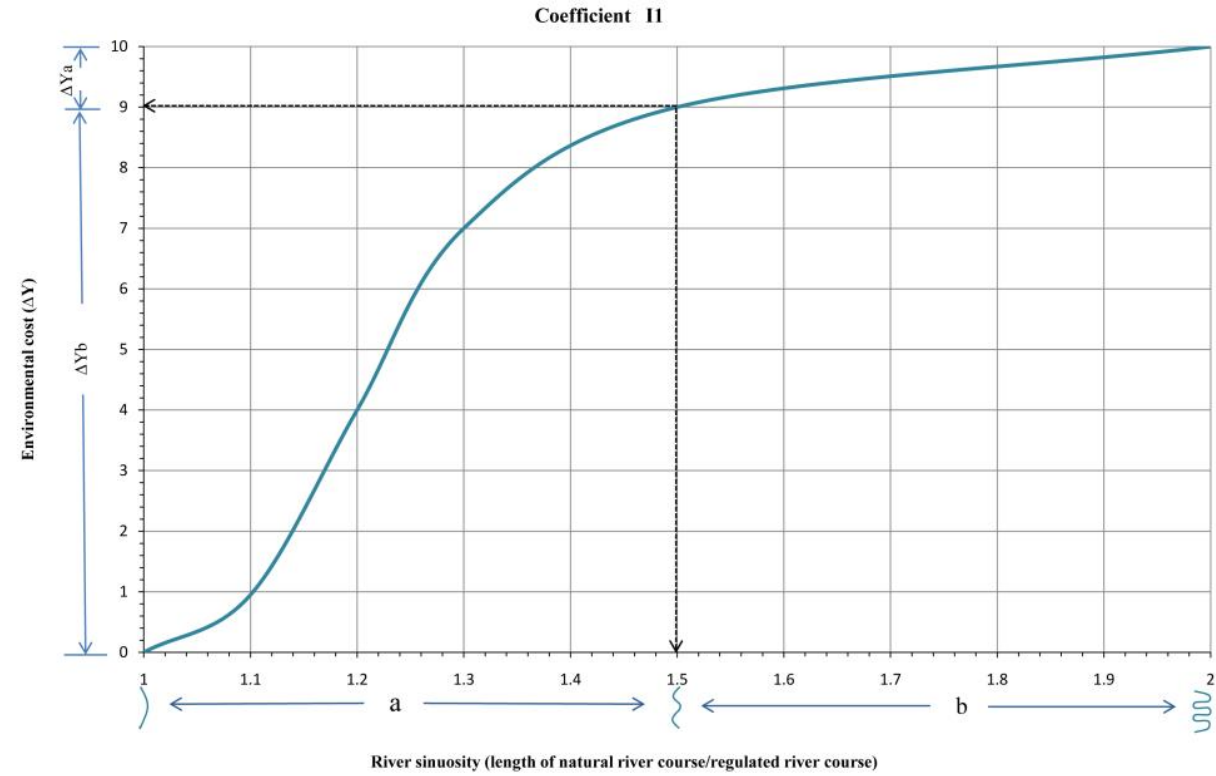

Fig. 3 Environmental cost of sinuosity loss, encountered as a difference among the originally and designed sinuosity

The sinuosity $\mathrm{S}$ is expressed as a ratio of the water stream developed length (measured at the thalweg) and the artificial segment length, measured as a straight line between the thalweg points of the artificial segment end sections. The environmental cost $\Delta \mathrm{Y}$ is difference between the values corresponding $S$ sinuosity values, existing previously and subsequently to the river training works.

$2^{\text {nd }}$ factor - constraining of the water stream free flow space, measured by increased lateral contraction degree, imposed by the damming.

River free flow space is assessed in relation with the minor river bed real width $(w)$, concerned as measurement unit. The environmental cost value is expressed by the $I_{2}$ coefficient and is established using the graph in figure 4.

Consequently, the origin major river beds, comparatively narrow, are deteriorated by damming in a much more severe manner than the comparatively wide river beds. 


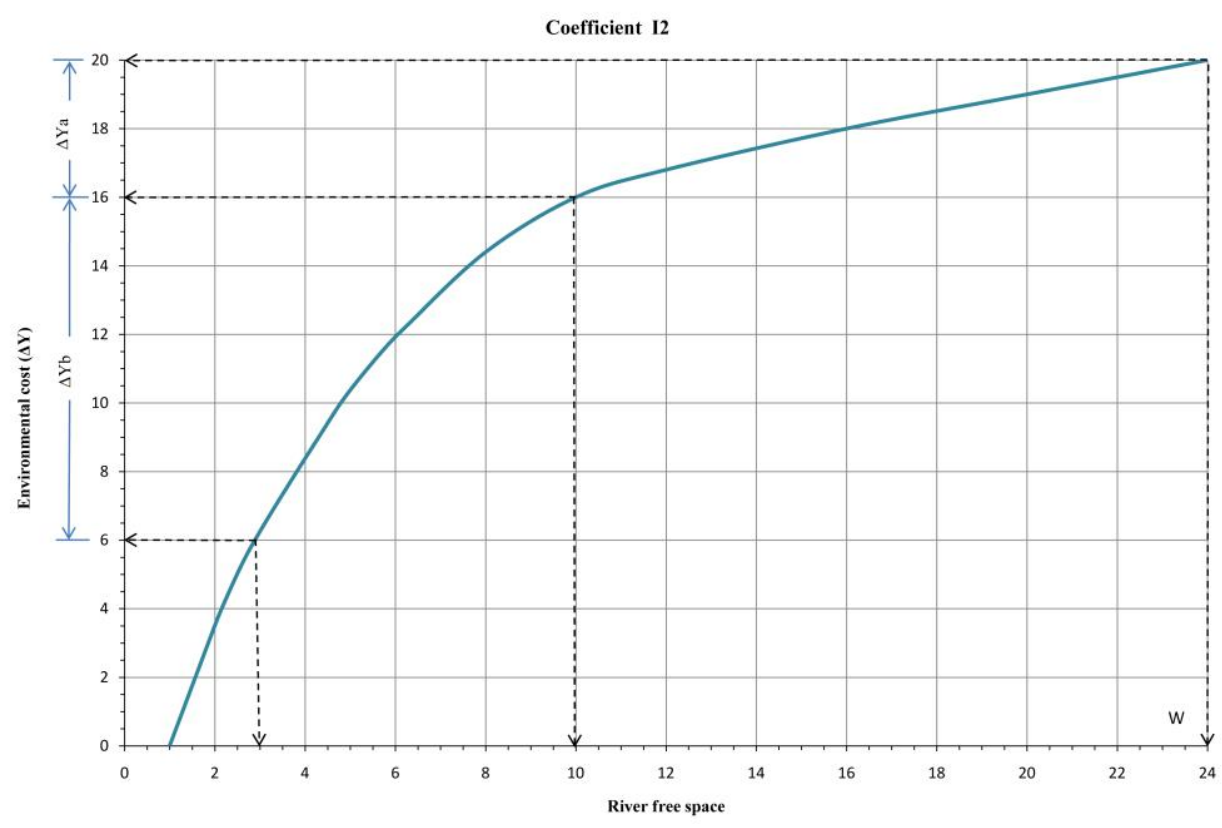

Fig. 4 Environmental cost of the river free flow space constraining

$3^{\text {rd }}$ factor - the return period of the minor bed load flow. A return period of one at every two years is considered as normal. The value of this parameter is established by hydrological surveys regarding the regional variability of the maximum annual flows.

The environmental cost value is expressed by the $\mathrm{I}_{3}$ coefficient and is determined using the graph in figure 5. For rivers with relatively limited return periods of minor river bed load flows the environmental costs are higher.

$4^{\text {th }}$ factor - increasing the flow width at low water flow (minimum average monthly flow) can generate the reduction of the medium depth, the excessive season water heating, and the winter frost and of the river bed silting. It is measured as $\%$ of the origin width. The environmental cost value is expressed by the $\mathrm{I}_{4}$ coefficient on the graph in figure 6 .

$5^{\text {th }}$ factor - alteration of the physical habitat structures and their connectivity is characterized by:

- disappearance of the quick-deep facies sequences, which is a major alteration of the physical environment;

- modification of the mineral and vegetal nature housing structures.

The environmental cost value is expressed by the $\mathrm{I}_{5}$ coefficient and is encountered using the graph in table 1.

$6^{\text {th }}$ factor - sublayer alteration, usually generated by earthworks, affects the river bed and modifies its granularity. The dislodging flow of the new river bed particles is established by classical hydraulic calculations; the recovery frequency of this flow enables the assessment of the sublayer instability risk. The comparison between the particles dislodging frequencies, before and after the works execution, namely the frequency difference, enables the quantification of the probable instability increase (minimal assessment). 


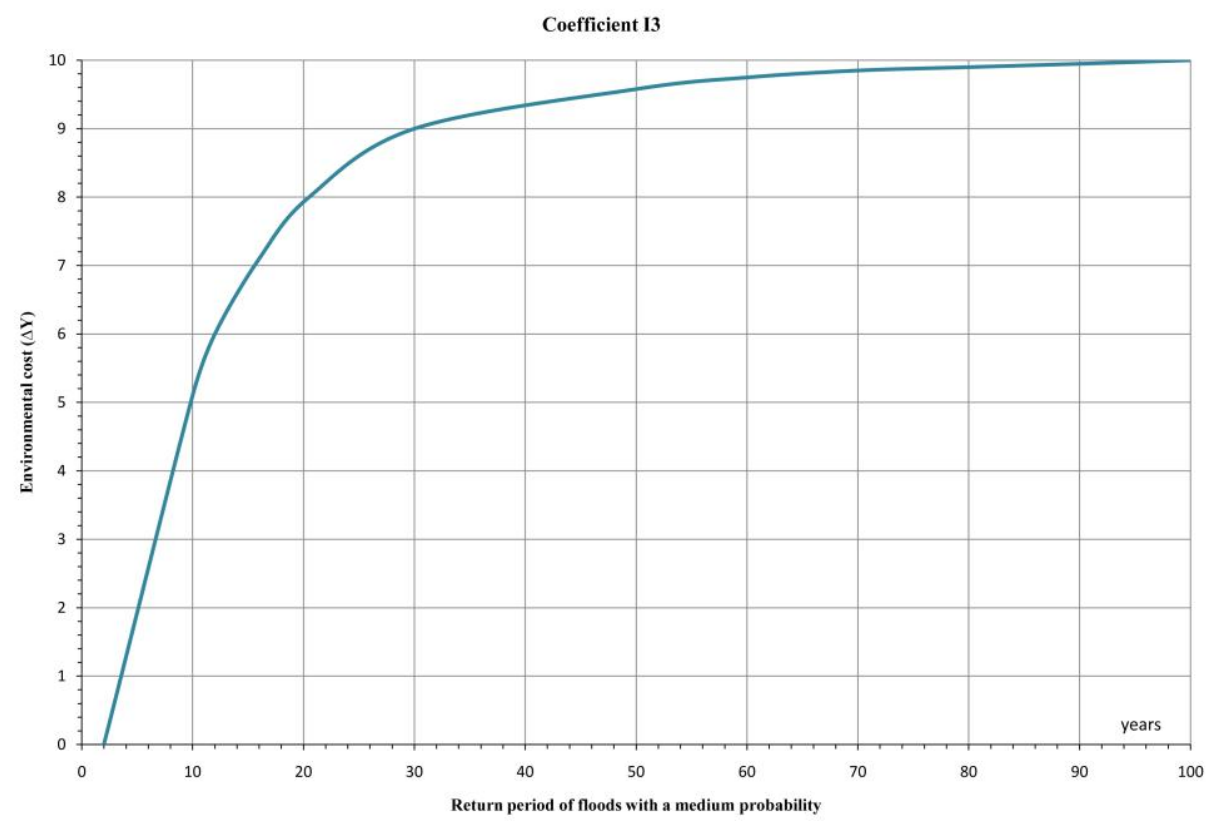

Fig. 5 Environmental cost of the minor bed load flow return period reduction

The environmental cost value of the sublayer alteration is expressed by the $\mathrm{I}_{6}$ coefficient and is established using the graph in figure 7. The forecast regarding the silting is extremely complex and it is not discussed in this study.

$7^{\text {th }}$ factor - loss of lateral connectivity, can be assessed by reducing the flooding area width, corresponding to the flood occurred once every 30 years at the real width of the minor river bed $w$. The environmental cost value is expressed by the $\mathrm{I}_{7}$ coefficient and is established using the graph in figure 8 .

$8^{\text {th }}$ factor-generation of artificial obstacles in the fishway passages, must be assessed on the entire river sector, depending on the possibility to pass the river training structures, at various flowing flows, and depending on the number of obstacles per kilometer of sector. The environmental cost value of the obstacles is expressed by the $\mathrm{I}_{8}$ coefficient and is established using the graph in figure 9.

Total artificialisation intensity per river sector unit is the sum of $I_{1} \ldots I_{8}$ coefficients.

d) Impact time. The assessment of the impact time period includes three elements:

- physical alteration remain (according to work reversibility);

- recurrence of the impact accumulation effect interventions;

- possible exacerbation of long term impacts, especially if the dynamic morphological balance is disturbed. 
Coefficient I4

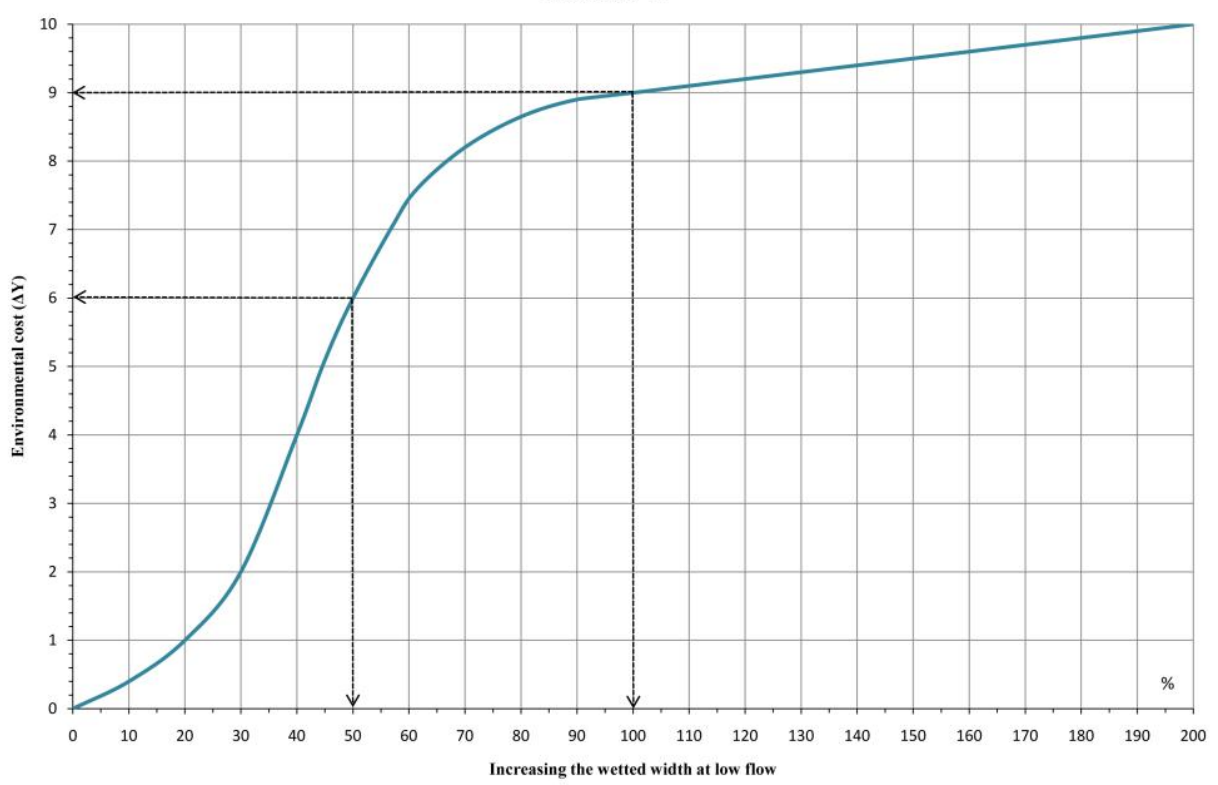

Fig. 6 Environmental cost of increasing the wetted flow width at low flow

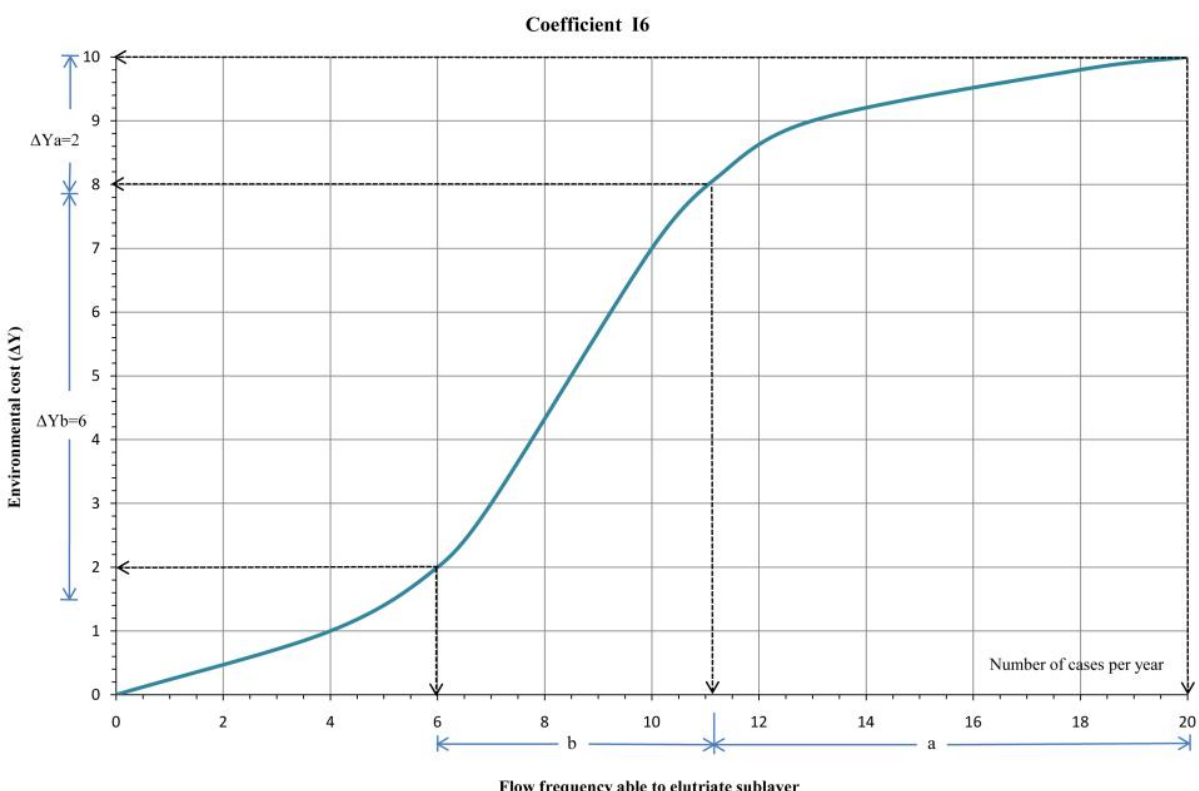

Fig. 7 Environmental cost value of the sublayer alteration 
Table 1 The environmental costs of the of physical habitats structure alteration $\mathrm{I}_{5}$

\begin{tabular}{lcc}
\hline \multirow{2}{*}{ Physical alteration } & \multicolumn{2}{c}{ Environmental cost } \\
\cline { 2 - 3 } & \multicolumn{2}{c}{ Stream energy } \\
\cline { 2 - 3 } 1 = Removing the wood structures sunk in the embankment & 3 & Low \\
$2=1+$ Banks levelling (re-embankment, removing blocks) & 7 & 10 \\
$3=2+$ Removing the obstacles from the canal (blocks, wood structures) & 12 & 12 \\
$4=3+$ Re-shaping, levelling of quick and slow facies & 20 & 20 \\
\hline
\end{tabular}

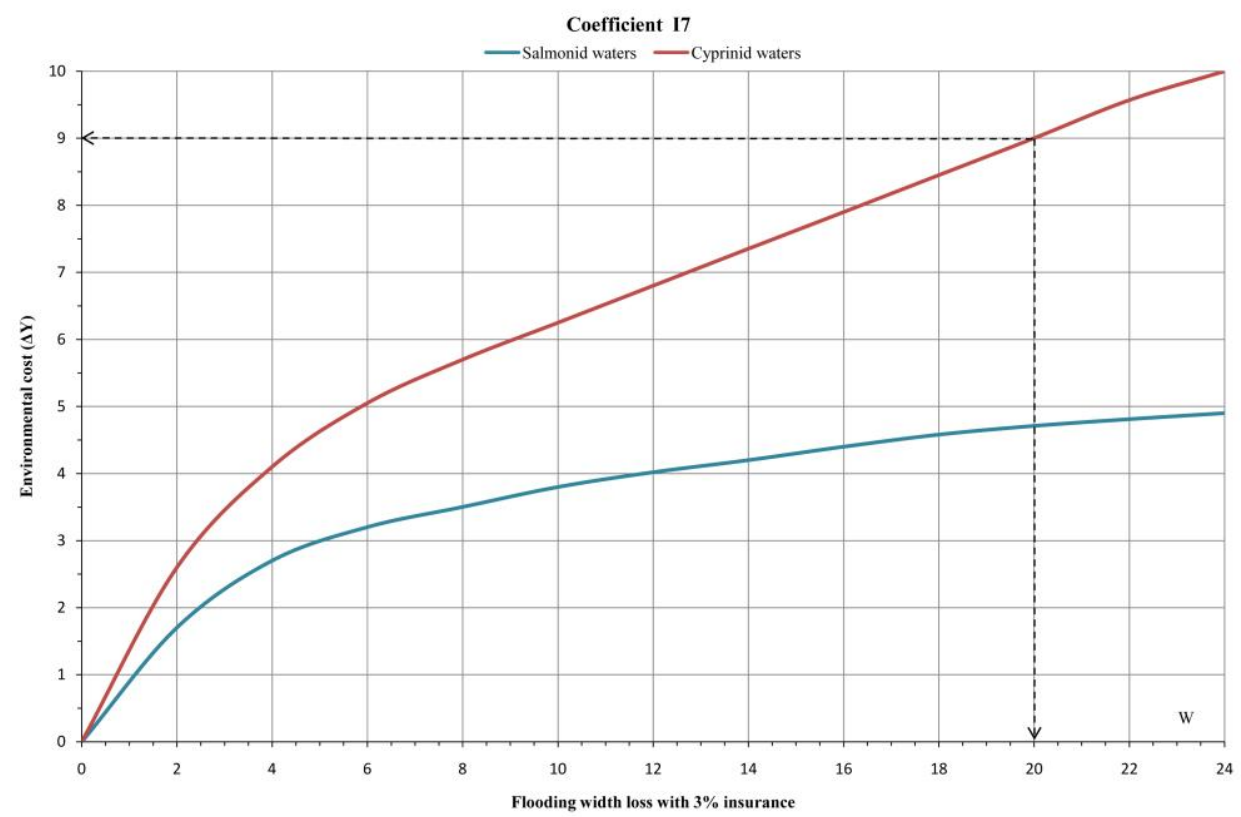

Fig. 8 Environmental cost of lateral connection forfeiture

The global impact solution parameter, generated by the regulation works solutions, marked by GIPS, is defined as follows:

$$
\begin{gathered}
G I P S=L \cdot I \cdot T \cdot \frac{w^{2}}{10^{4}} \\
L=\frac{l}{w} \cdot A \cdot R \\
I=I_{1}+I_{2}+\cdots+I_{8}
\end{gathered}
$$

$I_{1} \ldots I_{8}-$ partial intensity coefficients (defined according to the graphs and table 1);

$w^{2}-$ hectares surface of each artificialized lineal unit;

$A-$ segment characteristics coefficient (due to the graph in figure 1); 
$R$ - river rank coefficient (due to the graph in figure 2);

$T$-impact time (years).

Establishing the overall impact parameter extremely important for and is used to compare different river training works solutions, during the design phase, in order to select the most advantageous solutions, based on morphological and environmental criteria, as well as to establish the decisions regarding the restoration of certain river sectors. GIPS value may be one of the decision criteria of the multi criteria assessment.

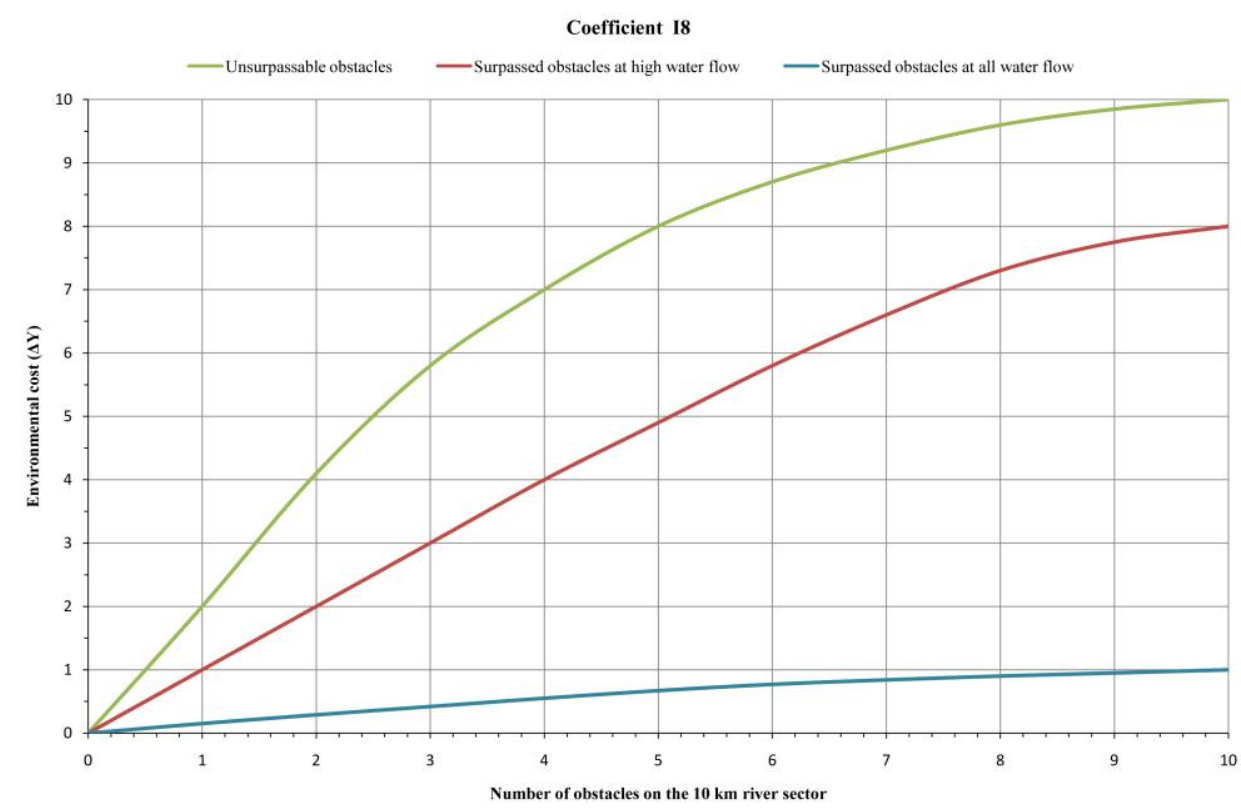

Fig. 9 Environmental cost of the artificial obstacles encountered on the fish migration path

\section{IMPACT OF CONSTRUCTIVE SOLUTIONS ON THE RIVER BED ARTIFICIALIZATION}

The previous assessment considers only the regulation solutions, thus the impact intensity must be quantified by also considering the real river training constructive solutions. The total impact parameter, stated by the construction solutions, GICS is calculated based on the following equation:

$$
G I C S=A \cdot R \cdot I_{C} \cdot T \cdot\left(\frac{l}{w}\right) \cdot \frac{w^{2}}{10^{4}}
$$


Table 2 Environmental costs of the construction solutions $-\mathrm{I}_{\mathrm{c}}$ coefficient

\begin{tabular}{|c|c|c|c|c|}
\hline \multirow{2}{*}{$\begin{array}{l}\text { Adaptability } \\
\text { to distortions }\end{array}$} & \multirow{2}{*}{ Materials nature } & \multicolumn{3}{|c|}{ Vegetation growth } \\
\hline & & Favorable & Unfavorable & Special \\
\hline \multirow{3}{*}{ Plastic structures } & Natural & 0 & 2 & - \\
\hline & Mixt & 2 & 4 & 1 \\
\hline & Artificial & 4 & 7 & 4 \\
\hline \multirow{3}{*}{ Rigid structures } & Natural & 4 & 8 & - \\
\hline & Mixt & 6 & 9 & 5 \\
\hline & Artificial & 8 & 10 & 6 \\
\hline \multirow{3}{*}{$\begin{array}{l}\text { Structures withstanding } \\
\text { limited distorsions }\end{array}$} & Natural & 2 & 5 & - \\
\hline & Mixt & 4 & 7 & 3 \\
\hline & Artificial & 6 & 8 & 5 \\
\hline
\end{tabular}

\section{CASE STUDY}

The object of the interest is represented by a river section on a length of about $10 \mathrm{~km}$, of about $1.2 \mathrm{~m}^{3} / \mathrm{s}$.

From water quality aspect, the river is of $1^{\text {st }}$ category.

The section has a moderate ecological interest, since its stable aquatic ecosystems contain valuable Salmonide species (umber).

The river has a sweep section and it was relatively stable until two decades ago, subsequently appearing signs of morphological instability due to the increase of floods frequency (with average return periods of up to 50 years).

Thus, on the entire river section appear thalweg aggradations and bank erosion within the curve concavities, with the trend of meander amplification.

On a section of about $500 \mathrm{~m}$ length, erosions affect the main county road and a number of households, including dwellings, whose rehabilitation caused significant costs, adding to the costs of the eroded lands, permanently lost.

The general aspect of the banks affected by erosion, causing regular landslide and collapse of another part of the bank, is obviously very unpleasant.

Due to similar phenomena, on the mentioned river section, during the previous years, different regulation works have been already made on another 4 sections with a total length of $3.2 \mathrm{~km}$.

The main characteristics of the river bed on the section are the following: the minor river bed is well delimited from the major river bed; for flow rates determined by computation, of around 1:30 years, the minor river bed fills and gets an average width of about $w=36 \mathrm{~m}$.

For average flow rates, the width of the minor river bed is of about 15-20 m, while for low flow rates, it is less than $5 \mathrm{~m}$.

For big flow rates exceeding the frequency of 1:30 years, the riparian areas are flooded; on the right bank, the flood is limited by the public road which fulfills the role of a protection dam and jetty, while on the left bank such flow rate causes the flood of the major river bed on a width of about $300 \mathrm{~m}$, in this place being emplaced also several households.

Due to the river bed aggradations, silting and presence of potentially fossil wooden structures, the capacity to ensure the transition of high flow rate waters has significantly decreased. 
The area is popular and frequented as agreement and relaxation area, several boarding houses being emplaced on the above mentioned river section.

Three alternatives were analyzed for the river training works, as follows:

Solution 1 - Linear concrete channel, cutting the existing meanders, with a trapezoidal cross section; the side walls are made of concrete, the thalweg shall be consolidated by a concrete foundation plate of $30 \mathrm{~cm}$ thickness.

Solution 2 - Sinusoid channel similar with the natural route; the cross-section provides river bed protection with Macaferri mattress, protection of the bank with Macaferri gabions, respectively, of embankments with Macaferri mattresses and MACMAT geotextile structure with vegetation.

The channel length is $557 \mathrm{~m}$ while the natural river bed length (measured along the thalweg) is of $578 \mathrm{~m}$.

The base width is of $14 \mathrm{~m}$, while the total channel area width is of $32 \mathrm{~m}$.It is estimated an investment amount of $1.32 \mathrm{I}_{1}$.

Solution 3 - it is what we called ,alternative ,zero", consist no works, the river flows freely, under its natural regime.

Based on the above graphs and tables provided in the paper Wasson-a [3], while analyzing of the specific problems the following results:

Table 3 Global effect of river bed artificialization

\begin{tabular}{cccccccccccccc}
\hline Solution & $\mathrm{A}$ & $\mathrm{R}$ & $\mathrm{T}$ & $\mathrm{I}_{1}$ & $\mathrm{I}_{2}$ & $\mathrm{I}_{3}$ & $\mathrm{I}_{4}$ & $\mathrm{I}_{5}$ & $\mathrm{I}_{6}$ & $\mathrm{I}_{7}$ & $\mathrm{I}_{8}$ & $\mathrm{I}$ & $\mathrm{GIPS}$ \\
\hline $\mathrm{S} 1$ & 4.4 & 8 & 20 & 7.8 & 0 & 0 & 0 & 12 & 2 & 0 & 0 & 21.8 & 0.9766 \\
$\mathrm{~S} 2$ & 4.4 & 8 & 20 & 1 & 0 & 0 & 0 & 12 & 2 & 0 & 0 & 15.0 & 0.3930 \\
$\mathrm{~S} 3$ & 4.4 & 8 & 20 & 0 & 0 & 0 & 0 & 0 & 0 & 0 & 0 & 0 & 0.1000 \\
\hline
\end{tabular}

Table 4 Impact of constructive solutions on the river bed artificialization

\begin{tabular}{ccc}
\hline Solution & $\mathrm{I}_{\mathrm{c}}$ & GICS \\
\hline S1 & 10 & 0.4480 \\
S2 & 1 & 0.0262 \\
S3 & 1 & 0.0262 \\
\hline
\end{tabular}

\section{CONCLUSION}

The fundamental principle of sustainable management of river flows is the availability of good quality data and expert judgment based on exact scientific knowledge.

A method which characterizes the morphology of river flows and determines the quality of aquatic habitats are becoming increasingly important in the decision-making process in the planning process for environmental protection, especially as a component of the assessment of environmental impact [4].

Determination of the ecological status is based on calibration, and due to "referential" conditions for a given class of river flow. Basic physical characteristics of the reference conditions (natural river morphology), which reflect the "good" ecological status of river flows, can be directly obtained by forming a network of river sections, which are adopted as "completely or almost completely untouched." 
If such a network does not exist for a particular class of river flow, physical properties can be obtained indirectly - modeling or expert analysis. By definition, the river flows unchanged physical structure, or a great hydromorphological status, if they have good water quality, aquatic habitat supporting excellent ecological status [4].

These reference sections of the river, with the best features of river habitat and water quality in our country are located in underdeveloped areas, given that the water flows in the underdeveloped areas under pressure is very low, which means that almost intact. It is also important to note that the river flows in these areas have the best quality of river water, but mainly belong to the class I watercourse [5].

\section{REFERENCES}

1. S. Petkovic, „Savremeni pristup uredjenju vodotoka“, Vodoprivreda, 2002, 2001/1-6, pp. 189 - 194

2. M. Markovic, „Multi Criteria Analysis of Hydraulic Structures for River Training Works“, Water Resource Management, 2012, Volume 26, Issue 13, pp. 3893-3906

3. J.G. Wasson, J.R Malavoi, L. Maridet, Y. Souchon, L. Paulin, , Impacts écologiques de la chenalisation des rivières, Ministere de l'environnement“", Direction de L'Eau, 1998, Rapport final

4. P.J. Raven, N.T.H. Holmes, P.Charrier, F. H. Dawson, M. Naura, P.J. Boon, „Towards a harmonised approach for hydromorphological assessment of rives in Europe: a qualitative comparison of three survey methods. Aquatic Conservation, Marine and Freshwater Ecosystems “, 2002, Volume 12,Issue 4, pp. 405-424

5. M. Urosev, A. Milanovic, D. Milijasevic, ,Assessment of the river habitat quality in undeveloped areas of Serbia applying the RHS (river habitat survey) method“, Zbornik radova Geografskog instituta „Jovan Cvijić”, SANU, 2009, No. 59(2), str. 37-58

\section{PROCENA UTICAJA KONSTRUKCIJA ZA UREĐENJE REČNIH TOKOVA NA ŽIVOTNU SREDINU PRIMENOM OPŠTIH KOEFICIJENATA DENATURALIZACIJE}

Prirodni rečni tokovi $i$ njihove priobalne površine predstavljaju izvanredno značajne kompleksne, ekološke resurse. Klasičan pristup uređenju rečnih tokova usmeren je ka ispunjavanju osnovnih vodoprivrednih zahteva kao što su zaštita od poplava, zaštita priobalnih oblasti, osiguranje rečnog korita, i stvaranje adekvatnog priobalnog prostora za ekonomski razvoj. Ova rešenja mogu uticati na ekološku ravnotežu i kvalitet života ljudi. U ovom poglavlju prikazan je metod za prethodnu procenu uticaja konstrukcija za uređenje rečnih tokova na životnu sredinu. Ovaj metod ima osnovnu primenu u uporednoj analizi različitih projektantskih rešenja računskim parametrom naziva ,globalni uticaj denaturalizacije vodotoka“, često kraće definisanim i kao ,globalni uticaj-GI“.

Ključne reči: hidrotehničke konstrukcije, životna sredina, procena uticaja 